\title{
聴覚障害児におけるメ夕表象能力の発達と関連要因の検討
}

\author{
大原 重洋 ${ }^{1,2)}$ 廣田 栄子2)
}

要 約: 本研究では, 音声言語コミュニケーションを用いる, 平均聴力レベル $75.7 \mathrm{~dB}(46.2$ 〜 $110 \mathrm{~dB}, 1 \mathrm{SD} 22.7$ ) の聴覚障害幼児・児童 12 名（生活年齢 4 7 歳）の心の理論（Theory of Mind：ToM）の 2 領域課題の発達経緯を生活年齢 4 5 歳の聴力正常児 12 名と比較して検 討した，結果，ToM の 2 領域課題のうち，他者の行為意図理解の発達は，㧍抄む㸚 4 5 歳の 聴児の発達に相当していた。一方, 聴覚障害児は, 他者の信念理解に著しく遅滞する傾向にあ り，他者の視点に立ち他者の表象を思い浮かべるメ夕表象能力に困難を示した。聴覚障害児が メ夕表象能力を獲得するには, 聴児に比して高水準の言語発達段階を要した。 メ夕表象能力の 形成には, 平均聴力レベルの他, 言語発達年齢, 統語的に適切な構文産出が関与しており, 補 聴間值や, MLUm 発達等の要因との関連性は低かった。本研究のメ夕表象能力の発達と, 関 連する要因のデー夕は，基礎資料として有用と考えられた。

索引用語：聴覚障害，心の理論，メ夕表象，言語発達

\section{Analysis of Factors Related to Meta-Representational Development in Hearing-Impaired Children}

\author{
Shigehiro Oohara ${ }^{1,2)}$ and Eiko Hirota ${ }^{2)}$
}

\begin{abstract}
This study analyzed factors related to theory of mind (ToM) development in 12 hearing-impaired children aged 4-7 years whose average hearing level was 75-7 dB (46.2-110 $\mathrm{dB}, 1 \mathrm{SD} 22.7$ ), compared to 12 hearing preschoolers $4-5$ years old. Two ToM tasks, the "explanation of action task" and "false belief task," were evaluated. The results revealed no difference between hearing-impaired subjects and hearing subjects in ability to use mental state to explain causes of human action. On the other hand, hearing-impaired subjects delayed significantly in the false belief task compared to hearing subjects. Hearing-impaired children were likely to delay in meta-representational development, i.e. the ability of representational understanding of others' mind from the others' viewpoint. Hearing-impaired subjects had a higher language development level for acquiring meta-representational ability than hearing subjects. These results suggest that meta-representational development of hearing-impaired children is influenced more by hearing level, language development age or syntax-appropriate utterances than by the hearing threshold level of the aided or implanted ear or the mean length of utterance in morphemes. This study indicated the development of
\end{abstract}

豊田市こども発達センター難聴幼児通園施設なのはな11)：干471-0062 愛知県豊田市西山町 2-19

筑波大学大学院人間総合科学研究科 2 ： $=112-0012$ 東京都文京区大塚 3-29-1

${ }^{11}$ Nanohana Day Care Center for Children with Impaired Hearing, Toyota Municipal Child Development Center: 2-19 Nishiyamacho, Toyota-shi, Aichi 471-0062, Japan

${ }^{2}$ Graduate School of Comprehensive Human Sciences, University of Tsukuba: 3-29-1 Otsuka, Bunkyo-ku, Tokyo 112-0012, Japan 2013 年 6 月 21 日受稿 2013 年 9 月 24 日受理 
meta-representational ability in hearing-impaired children and the factors related to acquiring that ability. The results are useful as fundamental data for constructing language training programs.

Key words: hearing-impaired, theory of mind, meta-representation, language development

\section{はじめに}

幼児が，相手の気持ちや考え・願望等を推察して， 相手の行動を理解する態度を形成する過程は社会的な 認知能力の発達に伴って現れるもので, その発達状況 について, 心の理論（Theory of Mind：ToM）課題 を用いて説明されている ${ }^{1,2)}$.

すなわち, ToM 課題は, 初期には, 相手が特定の 意図をもって行動する「他者の行為意図」を理解し, 次いで，相手が自分とは違う固有の信念（思い·考え・ 願望他）をもって行動する「他者の信念の理解」にい たるという 2 領域の社会的認知能力の発達評価で構成 され ${ }^{2,3)}$ ，典型発達児では，前者は扔打むね 4 歳 2,4 , 後者は 5 歳 $1,3,5)$ には理解できるようになると報告され ている，前者は相手の表情や身体表現等を観察して相 手の行動を容易に理解できるが 2,6)，後者については， 幼児が自分と切り離した他者の心的状態の存在を仮定 する等, 理解には高次の表象能力を必要とすると指摘 されている゙!.

「他者の信念の理解」の発達段階については, ToM の代表的なものでは誤信念課題のうち場所移動課題 (standard location-change task) ${ }^{1)}$ を用いて, 評価さ れている。課題は，被検児に対し，(1)ネコが2つの箱 の一方（A）に玩具を隠して場面から消える. (2)次に, ウサギが現れ別の箱（B）に玩具を入れ替えて場面か ら消える。(3)それを知らないネコが戻ってくるという 状況を見せた後に，「ネコはどこを探すと思いますか」 と尋ねる。 それに対して, 最終的に玩具の入っている 場所（B）と答えずに，被検児が「ネコはウサギが入 れ替えたことを知らないので，Aの箱を探す」と答 えた場合に，他者の信念の理解ができた段階にあると 解釈する，すなわち，被検児自身とは別にネコの考え （信念表象）を推察する（メ夕表象する）能力が形成 された段階と考えられる1,3,6,7).

聴覚障害児においては，近年では，新生児聴覚スク リーニングの普及により，1歳前から早期療育が開始 されるようになり ${ }^{8,9)}$ ，併せて早期人工内耳装用によっ て音声言語発達が促進され ${ }^{10)}$, Remmel ら ${ }^{11)}$ は, 幼児 期に「他者の信念の理解」が可能になった（対象： $\mathrm{n}$
$=30,37 \sim 144$ カ月齢, 平均 90〜 $120 \mathrm{~dB})$ と報告した. 一方で, 言語獲得後にも他者の心的状態を推察して行 動を予測する等の高次の表象的理解は困難であったと いう Peterson（対象： $\mathrm{n}=13,50 \sim 135$ ケ月齢, 平均 $91 \mathrm{~dB}$ 以上) ${ }^{12)}$, Levrez ら (対 象 : $\mathrm{n}=12,111$ 145 力月齢, 平均 70 90 dB 以上) ${ }^{13}$, Ketelaar ら (対 象: $\mathrm{n}=51, \quad 30 \sim 60$ 力月齢, 平均 $90 \mathrm{~dB}$ 以上 $)^{14)}$ の報 告もあり, 聴覚障害児の ToM 発達について一致した 見解が得られているとはいえない.

聴覚障害児における高次の表象的理解の遅れには, 統語産生力や語彙理解力等の言語発達の遅れの要因に ついて指摘されている15,16)。 また，コミュニケーショ ンモードとして聴覚口話法使用児では遅滞し, 聾家族 の手話使用児では遅れは少ないという点では見解は一 致している7 ${ }^{7,15)}$. しかし, 聴覚障害児については著者 の調べた範囲では, ToM の 2 領域の発達や, 対象児 の療育環境を一定にした検討はなく，療育指導の資料 として十分とはいえない.

そこで，本研究では，当療育施設で主に音声言語コ ミュニケーションを用いて指導した聴覚障害児の ToM の発達状況について, 典型発達児を対照として 検討した。併せて, ToM の 2 領域の発達を検討して, メ夕表象能力の発達拉よび関連する要因について明ら かにすることを目的とした。

\section{対象}

豊田市こども発達センター難聴幼览通園施設なのは な（以下，難聴児施設）の在籍児抒よび卒園児で，本 研究への協力の同意を得た先天性聴覚障害児 12 名 (男 11 名, 女 1 名, 生活年齢 48〜89 カ月, $1 \mathrm{SD} 14.3$ ) を 対象とし (以下, 聴障児群), 聴児 12 名 (男 5 名, 女 7 名）を比較対照とした（以下，聴児群）。対象児の プロフィールを表 1 に示した。 12 名の内，8名（e〜 1 児）は, 週 $1 \sim 2$ 回, 難聴児施設に母子通園し, 併 せて幼稚園·保育園に通園していた。 4 名 $(\mathrm{a} \sim \mathrm{d}$ 児) は, 難聴児施設卒園後, 通常小学校 ( $\mathrm{a}, \mathrm{c}, \mathrm{d}$ 児), 聾学 校 (b 児) の 1 学年に在籍し, 月 $1 \sim 2$ 回の言語指導 を継続した。

良聴耳の平均聴力レベル（四分法）は平均 $75.7 \mathrm{~dB}$ 
表 1 対象児の個人属性と発達検査結果

\begin{tabular}{|c|c|c|c|c|c|c|}
\hline & \multirow{2}{*}{ 生活年齢 } & \multirow[t]{2}{*}{ 性別 } & \multicolumn{2}{|c|}{$\begin{array}{c}\text { 聴力レベル } \\
\text { (dBHL) }\end{array}$} & \multirow{2}{*}{$\begin{array}{c}\text { 補聴 } \\
\text { 開始年齢 }\end{array}$} & \multirow{2}{*}{$\begin{array}{c}\text { 言語 } \\
\text { 発達年齢 }\end{array}$} \\
\hline & & & 裸耳 & 補聴耳 & & \\
\hline $\mathrm{a}$ & 89 & 男 & 48.7 & 27.5 & 44 & 90 \\
\hline b & 85 & 男 & 105.0 & 58.7 & 6 & 69 \\
\hline c & 84 & 女 & 71.2 & 35.0 & 37 & 70 \\
\hline d & 80 & 男 & 81.2 & 36.2 & 30 & 74 \\
\hline e & 72 & 男 & 51.2 & 36.2 & 38 & 64 \\
\hline $\mathrm{f}$ & 66 & 男 & 88.7 & 48.7 & 27 & 30 \\
\hline g & 63 & 男 & 92.5 & 31.2 & 23 & 48 \\
\hline h & 60 & 男 & 92.5 & 25.0 & 20 & 55 \\
\hline i & 53 & 男 & 110.0 & 35.0 & 6 & 55 \\
\hline $\mathrm{j}$ & 53 & 男 & 50.0 & 23.7 & 13 & 43 \\
\hline $\mathrm{k}$ & 48 & 男 & 46.2 & 30.0 & 14 & 48 \\
\hline 1 & 54 & 男 & 71.2 & 35.0 & 16 & 33 \\
\hline
\end{tabular}

生活年齢, 補聴開始年齢, 言語発達年齢は月齢で示した。 聴力レベル； 500～2000 Hz の聴力闇值四分法による算出結 果を示した.

$\mathrm{g}, \quad \mathrm{h}, \mathrm{i}$ 児の補聴耳䑌は人工内耳装用下の閾値 である。

(46.2 110 dB, $1 \mathrm{SD} 22.7$ ) であり, 補聴器・人工内 耳装用䦭值は平均 $35.1 \mathrm{~dB}(23.7 \sim 58.7 \mathrm{~dB}, 1 \mathrm{SD} 9.8)$ であった． 9 名（a〜f，j，k，1児）は補聴器を両耳装 用し， 3 名 $(\mathrm{g}, \mathrm{h}, \mathrm{i}$ 児) は人工内耳を片耳装用し, 反対耳に補聴器を装用していた。補聴器装用開始は,

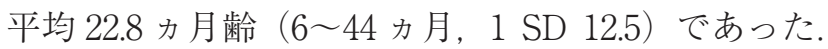
全例が聴者である両親から出生し，主に聴覚音声・読 話を用い，b，f 览は補助的に日本語対応手話を併用 した、いずれも聴覚障害以外に重複する障害を有して いなかった。言語発達については，新版 $\mathrm{K}$ 式発達検 査（言語社会領域）を用いて評価し，発達年齢は平均 56.6 カ月（1 SD 17.6）であった。

聴児群については，A 市立幼稚園に在籍する年中 児（4 歳台前半～ 5 歳） 17 名の内, 生活年齢より 4 力 月以上, 言語発達が遅滞する (KIDS 乳幼児発達スケー ル：生活年齢と言語領域・社会性領域に 4 力月以上乘 離） 2 例，さらに，保育担当者により対人関係および, 日常会話に課題が指摘された 3 例を除外した計 12 例 を対象とした．聴児について年中児を対象とした理由 は, ToM 課題は典型発達 4〜 5 歳で通過することによ $る^{1-6)}$. 聴児群の生活年齢は平均 56 力月 $(48 \sim 61$ 力月, $1 \mathrm{SD} 3.6)$ であり, 聴障児群の言語発達年齢との間に 統計的な差は認められなかった。

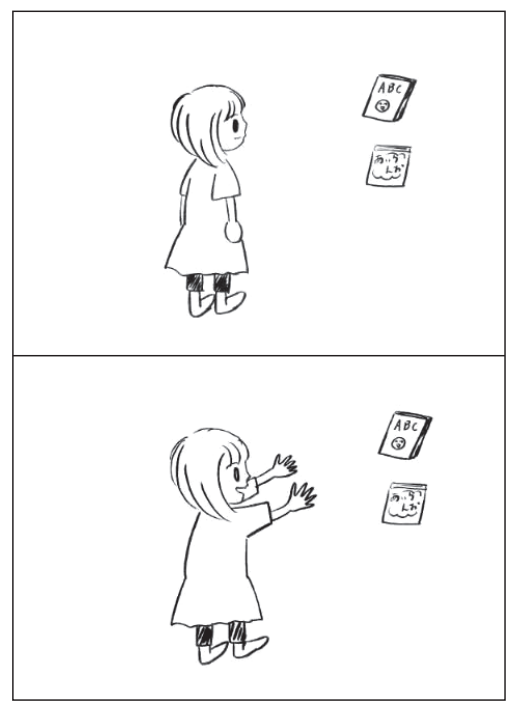

図 $1 a$ 欲求の図版例

図版を上から順に提示して「女の子が本を見ていま す。女の子が本に手を伸ばしました」と命題文を述 ベ，「どうして，手を伸ばしたと思いますか」と質 問した。

\section{方法}

\section{ToM (Theory of Mind) の評価}

1) 他者の行為意図理解課題 (explanation of action task $)^{2,4)}$

被検児に，行為者と連続する状況が描かれた 2 枚の 図版を提示しながら命題文を述べて，行為者の行動理 由について質問し回答を求めた。課題は行動理由 3 種 （欲求, 情動, 認知, 各 3 問）計 9 問であり, たとえば, 欲求の命題文例（図 1a）では「女の子が本を見てい ます。女の子が本に手を伸ばしました」と述べ，「ど うして，手を伸ばしたと思いますか」と質問した（初 回質問)。心的動詞による回答表現が得られない場合 には「この子は，どんな気持ちかな」といったプロー ブ質問を行った。

質問に対し，被検児が命題文に関連した心的動詞を 含み，適切な行動理由で回答した場合に課題通過とし 1 点を配点し，プローブ質問での正答には初回質問の 得点に 1 点を加え, それぞれ 9 問計 9 点を満点とした. 評価基準（表 $2 \mathrm{a}$ ） と被検児に提示した命題文，質問 文および回答表現の例（表 2b）を示した.

2) 他者の信念の理解課題（場所移動課題： standard location-change task $)^{1)}$

誤信念課題の場所移動課題（図 1b）については, 被検児の目前で 2 つの人形を操作しながら命題文を提 示した。課題は，被検児に対し，(1)ネコが 2 つの箱の 


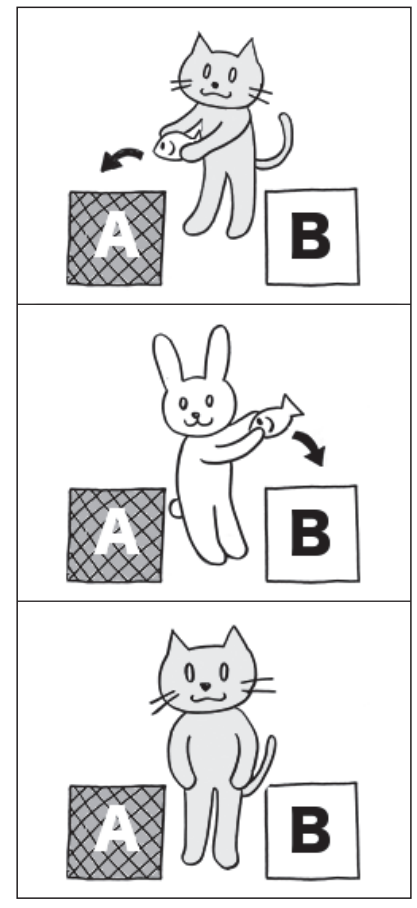

図 $1 b$ 場所移動課題の手続き

(1)ネコが玩具を 2 つの箱の内，1つに隠して場面から消える. (2)その間に, ウサギが現れ別の箱に入れ替えて場面から消える. (3)入れ替わったことを知らないネコが戻ってくる.

一方（A）に玩具を隠して場面から消える。（2)次に， ウサギが現れ別の箱（B）に玩具を入れ替えて場面か ら消える。(3)それを知らないネコが戻ってくるという 状況を見せた後に，3種の質問を順次実施した．表象 質問「ネコはどこを探すと思いますか」,現実質問「玩 具は今どこにありますか」，記憶質問「ネコが最初に 隠したのはどこですか」と問い，回答を求めた．

表象質問と記憶質問に対して, 被検児は最初にネコ が玩具を隠した箱（A）と回答し，現実質問に対して は，最終的に玩具が入っている箱（B）と回答した場 合に正答となる。すなわち, 被検児が表象質問では, 被検児自身が見ていることとは別に，ネコの視点でネ コの信念表象を思い浮かべる (メ夕表象する) 能力が

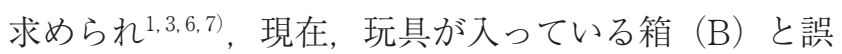
答した場合には，ネコの信念表象の推察ができていな いものとした，なお，表象質問に誤答した場合は「ネ コはウサギが入れ替えたことを知らない」ことを説明 した後に再度質問し, 課題状況の理解を確認した。

課題は聴覚音声・読話を用いて実施し, 口頭で被検 児に回答を求め, $b, f$ 児に対しては, 日本語対応手話・ 指文字，筆記を併用した。

\section{2 . 言語発達水準の検討}

1) 聴障児群の療育場面において各対象児につい
表 2a 行為意図理解課題の評価基準

\begin{tabular}{cl}
\hline $\begin{array}{c}\text { 心的動詞の } \\
\text { 機能分類 }\end{array}$ & 評価基準 \\
\hline & 「○したい」「欲しい」といった欲求に関連し \\
欲求 & た動詞が含まれていることが必要. 単に, 主人 \\
& 公の動作を表現したものは不通過とする(以下, \\
& 同じ). \\
& 「びっくりする」「驚く」「恐くなる」「嫌う」「悲 \\
& しむ」「怒る」といった感情に関連した動詞が \\
& 含まれていることが必要.「嫌う」等を「嫌だ」 \\
& と名詞句で表現しても通過とする. 欲求, 認知 \\
& に関連した動詞で回答したとしても, 不通過と \\
& する. \\
& 「知る」「教える」「真似をする」「振りをする」「忘 \\
& れる」といった認知に関連した動詞が含まれて \\
& いることが必要. 認知に関連した動詞を用いて \\
& いても, 「知る」に対して「忘れる」を用いた \\
& 場合等, 的確でない使用は不通過とする. \\
\hline 認知 &
\end{tabular}

て，50 発話サンプルを採取し録音した。発話の間を つなぐ「えっと」「なんか」といったフィラーや不明 瞭な箇所を除外して発話を文字転記し形態素分析を 行った ${ }^{17)}$. 各児の総形態素数を全発話数（50 発話） で除して形態素単位平均発話長 (Mean Length of Utterance in Morphemes: MLUm）を算出した.

2 ) 文法的に誤りのない構文の発話数を全発話数 (50 発話）で除して統語の適正率を算出した。「車で家で 帰った（車で家に帰った），「鬼に豆にまく（鬼に豆 をまく)」といった格助詞の誤用，「服入ってるよ（服 着ているよ)」といった動詞の意味の共起性等の誤用 とし, 言いよどみやて長な繰り返し, 会話時の助詞, 動詞の自然な省略は誤用としなかった。

3 ) 臨床心理士が新版 K 式発達検査 (言語社会領域) を用いて評価し，言語発達年齢を算出した。

\section{3. 結果の解析法}

聴障児群における ToM の 2 領域課題の結果につい て聴児群と比較し統計学的に検討した（行為意図理解 課題：対応のない $\mathrm{t}$ 検定, 場所移動課題 : $\chi^{2}$ 検定). さらに, 場所移動課題の通過の可否により聴障児群を 2 群に分け, 両群間の平均聴力レベル, 言語発達年齢, 発話産出（MLUm, 統語の適正率）の差について解 析し, メタ表象の発達に関与する要因について検討し た。

本研究は, 豊田市こども発達センター研究倫理審査 委員会の承認を得て実施した。個人情報の取り扱いに ついては, 研究目的以外では使用しないこと, 公開に は統計的に集計・整理して個人情報の守秘義務を厳守 
表 $\mathbf{2 b}$ 命題文/質問文/回答表現の例

\begin{tabular}{|c|c|c|c|c|}
\hline $\begin{array}{l}\text { 心的動詞の } \\
\text { 機能分類 }\end{array}$ & 命題文 & 質問文 & 正答例 & 誤答例 \\
\hline \multirow{3}{*}{ 欲求 } & $\begin{array}{l}\text { 女の子が本を見ています．女の子 } \\
\text { が本に手を伸ばしました. }\end{array}$ & $\begin{array}{l}\text { どうして手を伸ばし } \\
\text { たと思いますか？ }\end{array}$ & $\begin{array}{l}\text { ·本が見たいから. } \\
\text { ·本を欲しいと思って. }\end{array}$ & $\begin{array}{l}\text { ·本を読んでいる. } \\
\text { ·本をもらったから. }\end{array}$ \\
\hline & $\begin{array}{l}\text { 女の子がお母さんと買い物をして } \\
\text { います. 女の子が, お菓子を指差 } \\
\text { しました. }\end{array}$ & $\begin{array}{l}\text { どうして指差したと } \\
\text { 思いますか？ }\end{array}$ & $\begin{array}{l}\text { ・これ買って欲しいってさ } \\
\text { した. } \\
\text { ・アイスが食べたいと思っ } \\
\text { た. }\end{array}$ & $\begin{array}{l}\text { ·アイス食べちゃった. } \\
\text { ·おいしいから. }\end{array}$ \\
\hline & $\begin{array}{l}\text { 女の子が玩具を見ています．女の } \\
\text { 子がサンタさんに手紙を書いてい } \\
\text { ます. }\end{array}$ & $\begin{array}{l}\text { どうしてサンタさん } \\
\text { に手紙を書いたと思 } \\
\text { いますか? }\end{array}$ & $\begin{array}{l}\text { ·玩具屋さんで見て, サン } \\
\text { タさんに欲しいってたの } \\
\text { んだ. } \\
\text { ・プレゼントもらいたいか } \\
\text { ら. }\end{array}$ & $\begin{array}{l}\text { ・プレゼントどうぞって. } \\
\text { ・サンタさんにお手紙を書 } \\
\text { くから. }\end{array}$ \\
\hline \multirow{3}{*}{ 情動 } & $\begin{array}{l}\text { 女の子が箱を開けると, 中から玩 } \\
\text { 具が飛び出しました. 女の子は飛 } \\
\text { 上がりました. }\end{array}$ & $\begin{array}{l}\text { どうして女の子は飛 } \\
\text { 上がったと思います } \\
\text { か？ }\end{array}$ & $\begin{array}{l}\cdot \text { びっくりしたから. } \\
\cdot \text { 怖かったから. }\end{array}$ & $\begin{array}{l}\text { ·間違えたから. } \\
\text { ・この人が゙ゅゅっ出てき } \\
\text { たから. }\end{array}$ \\
\hline & $\begin{array}{l}\text { 女の子が寝ている犬を見ていまし } \\
\text { た. 犬が起き上がって追いかけて } \\
\text { きました. 女の子は逃げました. }\end{array}$ & $\begin{array}{l}\text { どうして逃げたと思 } \\
\text { いますか？ }\end{array}$ & $\begin{array}{l}\text { 恐かったから. } \\
\text { 嫌だなーって思ったから } \\
\text { 逃げた. }\end{array}$ & $\begin{array}{l}\text { · 犬が起き上がったから. } \\
\text { ・だって, ワンワンって言っ } \\
\text { たら, 逃げちゃった. }\end{array}$ \\
\hline & $\begin{array}{l}\text { 女の子が人形で遊んでいると, 男 } \\
\text { の子が来て, 人形を取り上げまし } \\
\text { た. 女の子は男の子に石を投げま } \\
\text { した. }\end{array}$ & $\begin{array}{l}\text { どうして石を投げた } \\
\text { と思いますか？ }\end{array}$ & $\begin{array}{l}\text { 悲しい気持ちで，石を投 } \\
\text { げた. } \\
\text { ・人形を取られて，怒っ } \\
\text { ちゃった. }\end{array}$ & $\begin{array}{l}\text { ·男の子が人形を取ったも } \\
\text { ん. } \\
\text { ·まだ人形で遊びたいから. }\end{array}$ \\
\hline \multirow{3}{*}{ 認知 } & $\begin{array}{l}\text { 女の子が赤ちゃんと玩具で遊んで } \\
\text { いました. 赤ちゃんが車の鍵を玩 } \\
\text { 具の一つに入れてしまいました. } \\
\text { お母さんは女の子を呼びました. }\end{array}$ & $\begin{array}{l}\text { どうしてお母さんは } \\
\text { 女の子を呼んだと思 } \\
\text { いますか? }\end{array}$ & $\begin{array}{l}\text { ·女の子が,鍵の場所を知っ } \\
\text { ていると思ったから. } \\
\text { ·お姉ちゃんに教えてもら } \\
\text { うため. }\end{array}$ & $\begin{array}{l}\text { ・お母さんは車を運転した } \\
\text { いから. } \\
\text { ・赤ちゃんが鍵を隠し } \\
\text { ちゃった. }\end{array}$ \\
\hline & $\begin{array}{l}\text { 女の子が公園でチョウチョが飛ん } \\
\text { でいるのを見ていました。 女の子 } \\
\text { は, 両手を広げて上げたり, 下げ } \\
\text { たりしました. }\end{array}$ & $\begin{array}{l}\text { どうして女の子は両 } \\
\text { 手を広げて上げた } \\
\text { り, 下げたりしたと } \\
\text { 思いますか? }\end{array}$ & $\begin{array}{l}\text { ·チョウチョの真似をして } \\
\text { いる. } \\
\text { ·チョウチョになっている } \\
\text { つもりだから. }\end{array}$ & $\begin{array}{l}\text { ·チョウチョを逃がそうと } \\
\text { 思った. } \\
\text { ·飛ぼうと思ったから. }\end{array}$ \\
\hline & $\begin{array}{l}\text { 女の子が傘を持ってバスに乗って } \\
\text { います. バスから降りたら雨が } \\
\text { 降っていて, びしょ濡れになりま } \\
\text { した. }\end{array}$ & $\begin{array}{l}\text { どうして濡れたと思 } \\
\text { いますか? }\end{array}$ & $\begin{array}{l}\text { ·釡を忘れたと思っている. } \\
\text { •バスに忘れてきた. }\end{array}$ & $\begin{array}{l}\text { ・傘がないから. } \\
\text { ・濡れちゃったと思ってい } \\
\text { る. }\end{array}$ \\
\hline
\end{tabular}

正答例の下線部に心的動詞を示した。

することを被検児の保護者ならびに幼稚園の園長に文 章で説明して，研究協力の同意を得た。

\section{結果}

\section{ToM の課題評価}

1 ）他者の行為意図理解課題

表 3 に聴障児群と聴児群の行為意図理解課題の結果 を比較して示した。聴障児群の初回質問の平均得点は 3.5（1 SD 2.2）, 聴児群 4.6（1 SD 1.6）であり，また, プローブ質問では聴障児群 5.6（1 SD 2.8），聴児群 6.5 (1 SD 1.8) で，いずれも群間に統計的な差が認めら
れなかった。 なお，両群ともに初回質問に比べてプロー ブ質問では心的動詞を用いた回答が増加しており，言 語的な働きかけは他者の心的状態への意識を導く効果 があることが示された。

下位項目では, 初回質問の情動項目にのみ, 聴障児 群 $0.8 （ 1$ SD 0.7）は聴児群 $1.5 （ 1$ SD 0.5）より低下し, 統計的有意差を認めた $(\mathrm{p}<0.05)$. 欲求項目の得点が 両群とも最も高く, 認知項目が最も低い傾向を示した. 「他者の行為意図の理解」に関しては, 聴障児群は 4 ～5 歳の典型発達児と同程度の理解水準にあることが 示された。 
表 3 行為意図理解課題

\begin{tabular}{lll}
\hline & 聴覚障害児 & \multicolumn{1}{c}{ 聴児 } \\
\hline 初回質問 & & \\
欲求 & $1.9(1.1)$ & $2.3(1.0)$ \\
情動 & $0.8(0.7)$ & $1.5(0.5)^{*}$ \\
認知 & $0.7(0.9)$ & $0.8(0.7)$ \\
総得点 & $3.5(2.2)$ & $4.6(1.6)$ \\
プローブ質問 & & \\
欲求 & $2.3(1.0)$ & $2.6(0.8)$ \\
情動 & $1.8(1.1)$ & $2.5(0.5)$ \\
認知 & $1.5(0.9)$ & $1.3(0.9)$ \\
総得点 & $5.6(2.8)$ & $6.5(1.8)$ \\
\hline
\end{tabular}

最大得点：下位項目 3 , 総得点 $9, \quad(\quad): 1 \mathrm{SD}$, * $\mathrm{p}<0.05$.

注) プローブ質問は，プローブ質問を行った後の 質問 +プローブ質問の合計得点である.

表 4 場所移動課題

\begin{tabular}{lccc}
\hline & 表象質問 & 現実質問 & 記憶質問 \\
\hline $\begin{array}{l}\text { 聴覚障害児 } \\
(\mathrm{n}=12)\end{array}$ & $4 / 33.3$ & $12 / 100$ & $12 / 100$ \\
$\begin{array}{l}\text { 聴児 } \\
(\mathrm{n}=12)\end{array}$ & $10 / 83.3$ & $12 / 100$ & $12 / 100$ \\
\hline & \multicolumn{3}{l}{ 前に人数, 後に\%を示した. }
\end{tabular}

\section{2 ）他者の信念の理解課題（場所移動課題）}

表 4 に場所移動課題の通過児数を示した．聴障児群 では 4 名 (33.3\%) に対し，聴児群は10名（83.3\%） と通過例数比率は高く，差は統計的に有意であった $(p<0.01)$ ．全例について，現実質問，記憶質問に誤答 はなく，また，表象質問に誤答した聴障児群 8 名，聴 児群 2 名に対し，課題状況を説明後に再度質問して通 過にいたらなかったものの, 全例が課題状況を理解し て回答したことが確認された。「他者の信念の理解」 について，聴障児は 4〜5 歳の典型発達児に比べて低 下し，誤信念の表象的理解に著しい困難を示した。

\section{2.メタ表象形成に関連する要因}

\section{1) 平均聴力レベル}

聴障児群 12 名について, 場所移動課題の通過群 $a, b$, $\mathrm{c}, \mathrm{k}$ 児の 4 名と, 不通過群 $\mathrm{d} \sim \mathrm{j}, 1$ 児の 8 名の 2 群に 分類し，各種要因の影響を検討した。通過群では，平 均聴力レベルの中央值は $59.9 \mathrm{~dB}(46.2 \sim 105 \mathrm{~dB})$ で あり，重度児 1 例（b 児），高度児 1 例（c 児）, 中等 度児 2 例（a， k 児）であった。一方，不通過群の中 央值は $84.9 \mathrm{~dB}(50 \sim 110 \mathrm{~dB})$ であり, 重度児 3 例（g, $h, I$ 児), 高度児 3 例 (d, f, l 児), 中等度児 2 例 (e, $\mathrm{j}$ 児）と, 通過群に比べて平均聴力レベルが高い傾向 を示した。補聴閾值の中央值は，通過群 $32.5 \mathrm{~dB}(27.5$
表 5a 通過群の平均発話長 (MLUm)

\begin{tabular}{cclc} 
対象児 & MLUm & 主な発話例 & 統語適正率 $(\%)$ \\
\hline $\mathrm{a}$ & 4.0 & ベんきょう/じゃ/ない/んだ/から & 100 \\
$\mathrm{~b}$ & 1.9 & ○○せんせい/に/もらう & 100 \\
$\mathrm{c}$ & 3.2 & ぎゅうにゅう/が/こぼれ/ちゃ/った & 94 \\
$\mathrm{k}$ & 3.1 & まめ/を/まい/ている/と/おもう & 100 \\
中央值 & 3.2 & & 100
\end{tabular}

表 $5 \mathbf{b}$ 不通過群の平均発話長 (MLUm)

\begin{tabular}{|c|c|c|c|}
\hline 対象児 & MLUm & 主な発話例 & 統語適正率 (\%) \\
\hline $\mathrm{d}$ & 3.7 & ここ/が/つい/ている/むし & 88.4 \\
\hline e & 5.2 & いっ/てみ/て/わから/ん & 87.0 \\
\hline $\mathrm{f}$ & 2.9 & おねえちゃん/は/すこっぷ/に & 72.5 \\
\hline $\mathrm{g}$ & 4.0 & $\begin{array}{l}\text { さくら/の/バス/のっ/て/さくらこう } \\
\text { えん/いっ/た. }\end{array}$ & 87.7 \\
\hline $\mathrm{h}$ & 3.7 & うしろ/で/すべりだい/で/すべっ/た & 84.6 \\
\hline $\mathrm{i}$ & 4.3 & おばけ/みたい/に/ばね/じゃない & 92.5 \\
\hline $\mathrm{j}$ & 2.3 & せんせい/は/あめ/ふって & 95.5 \\
\hline 1 & 3.3 & $\begin{array}{l}\text { ちゅうしゃじょう/いきす/きゅう } \\
\text { きゅうしゃ }\end{array}$ & 93.8 \\
\hline 中央值 & 3.7 & & 88.0 \\
\hline
\end{tabular}

$\sim 58.7 \mathrm{~dB})$ ，不通過群 $35 \mathrm{~dB}(23.7 \sim 48.7 \mathrm{~dB})$ と群間 差は少なかった。

2 ) 言語発達

聴障児群の通過群は 4 名中 3 例（a， b， c 児）が 7 歳児で, 言語発達年齢の中央值は, 通過群は 69.5 力 月 (48〜90 力月), 不通過群 51.5 力月 (30〜 74 力月) と生活年齢が反映した結果となった。聴障児群 12 名 例中 9 名 (f, j, 1 児 3 名を除く）は 4 歳以上の言語 発達年齢の段階にあったが, 通過したのは 4 名（44\%） と半数以下であった.

表 5 に，聴障児群の MLUm と代表的な発話例およ び，統語の適正率を示した，MLUmの中央值は，通 過群では $3.2(1.8 \sim 3.9$, 1SD 0.8) で不通過群では 3.7 (2.2 〜 5.1, 1SD 0.8）といずれも発話は短く, 群間の差は 少なかった。聴障児群の MLUm 值について，典型発 達児の標準值を参照すると，おおむね 3 歳台前半に相 当し, 統語構造として複文等の使用が始まる段階に相 当するが18, 19)，実際には統語構造は単文が多く，複文 の使用は皆無であった。

統語の適正率については，通過群では中央值 100\% (94〜100\%) であり，不通過群では 88\%（72.5〜 95.5\%）と，通過群は統語的に適切な構文を使用する 傾向が高いといえる。 


\section{考察}

\section{1 . 聴障児の ToM の発達}

本研究では, 幼児〜学童期の聴障児における他者の 行為意図理解と, 他者の信念に関する表象的理解の発 達について，4５歳の聴児と比較して検討した。 そ の結果，聴障児群は，他者の行為意図理解については 聴児群の成績と同程度の理解水準にあることが確認さ れた。しかし, 場所移動課題の通過率は聴児群 (83.3\%) と比べて聴障児群（33.3\%）は低く，他者の信念内容 の表象的理解について, 著しい遅滞を示すことが明ら かとなった。

ToM の 2 領域（行為意図理解，信念内容の表象的 理解）の社会認知能力について, Tager-Flusberg ら ${ }^{2)}$ は, 課題通過に必要な発達的背景が異なることを指摘 し，他者の行為意図は表情や身体動作により容易に理 解できるが，一方，高次の表象的理解能力は言語，特 に補文構造の理解と密接に関連すると報告した。本研 究でも，聴障児群において他者の行為意図は聴児群の 理解水準と差はなく, 欲求項目の理解が容易で, 認知 項目の理解が困難であるという共通した傾向を示した ことから, Tager-Flusberg ら ${ }^{2)}$ の結果の一部を支持 するものであった。

\section{2.メタ表象の形成に関与する要因}

本研究では, 場所移動課題の通過の可否で聴障児群 を2 分し, メ夕表象能力の発達に関連する要因につい て検討した。その結果，通過群の言語発達年齢は不通 過群より高いことから，聴障児に㧍けるメタ表象の発 達に言語能力が関連するという報告7, 15, 13, 16, 20) を支持 する結果となった。

また, 聴障児の発話の統語的発達を検討するために, 療育指導場面の MLUm を算出しメ夕表象能力との関 連を検討した。その結果, MLUmの中央值は，通過 群 $3.2 （ 1.8 \sim 3.9$, 1 SD 0.8), 不通過群 3.7 （2.2 5.1, $1 \mathrm{SD} 0.8$ ) といずれも発話長は短く, 群間の差は少な いことを示した。一方，統語の適正率に関しては，通 過群の中央值は 100\%（94１00\%）であり，不通過群 88\%（72.5～95.5\%）と比べて高い傾向にあった，そこ で, メ夕表象能力の発達には, MLUmよりもむしろ, 日常会話において統語的に適切な構文を使用すること との関連性が高いと推察される。誤信念表象の理解と 補文構造の理解 ${ }^{15)}$ や統語産生力 ${ }^{11,16)}$ との関連が指摘 されており，難聴児施設等では個別評価に基づいた指 導により, 統語的に適切な構文発達の基盤を形成する ことの重要性を指摘できる。
なお，形態素数の発達は，女児に比し男児が遅れる 傾向が示されており ${ }^{17)}$ ，本研究では対象児 12 名中 11 名が男児であることから，性差の影響も排除できない ことに留意が必要である。

ところで，典型発達児は，お扔むね 4 5 歳で標準 的な誤信念課題を通過するとされており ${ }^{1-6)}$, 本研究 で比較対照とした聴児群の結果（83\%通過）も同様で あった。それに対し，聴障児で言語発達年齢 4 歳以上 を示す 9 名の内，同課題を通過したのは 4 名 (44\%) と半数以下であった。ささらに, 4 名中 3 名の言語発達 年齢は, 90 力月 ( $\mathrm{a}$ 児), 70 力月 ( $\mathrm{c}$ 児), 69 力月 ( $\mathrm{b}$ 児) と聴児群の通過年齢と比べて高い傾向にあり，聴障児 がメ夕表象能力の獲得にいたるには，聴児に比して高 水準の言語発達段階を必要とすることを指摘できる.

聴障児の聴力要因については, 不通過群は通過群よ り重度傾向を示し, 重度聴障児ではメ夕表象の学習が 困難であることが示された。補聴閾值の要因は関与し ていなかった。

\section{3. 療育における指針}

本研究では, 行為意図理解に関連した心的動詞の使 用に聴障児群と聴児群の差は少なかったが，心的動詞 に注目させることにより聴障児の行為意図理解を促進 したという報告もあり ${ }^{21)}$ ，言語聴覚士等による個別状 況に応じた発達支援の重要性が示唆された。

日常場面に本結果を汎用すると，聴障児では，他児 の見掛けの行為と本意が一致しない状況で，気持ちを 汲み取った（他者意図理解）対応ができないことが多 く，その際に療育担当者は，聴障児に相手の心理状態 を言語的に分かるように説明することが重要といえ る.

聴障児の ToM の発達においては, 社会認知発達後 期の「他者の視点に立ち,他者の表象を思い浮かべる」 という, メ夕表象能力の形成に困難があることが示さ れた。音声言語コミュニケーションを用いる幼児にそ の傾向が指摘されていることから ${ }^{7)}$, 早期からの日常 的な会話の文脈や語用的側面の指導, 手話・ジャス チャー等の使用等の有用性が示唆された，その際に本 研究の結果は, 指導計画立案の資料として有用である と考えられた。

\section{まとめと今後の課題}

本研究では，当難聴幼児療育施設で指導した先天性 聴障児 12 名について, 聴児 12 名と比較して ToM の 2 領域課題の発達について検討した。他者の行動の理 解に必要なメ夕表象能力の獲得については，平均聴力 
レベルのほか，言語発達年齢，適切な統語能力等の言 語能力要因の関連性について検討し，以下の結果を得 た。

1. 聴覚音声・読話を用いる 4 歳から小学校 1 年の 聴障児において, ToM の 2 領域課題における他者の 行為意図理解の能力は，扮おむね 4 歳の聴児の発 達に相当していた。

2. 他者の信念（誤信念課題）等, 高次の表象的理 解の能力については, 聴障児では遅滞を示す例が多 かった。

3. 聴障児がメ夕表象能力の獲得にいたるには, 聴 児に比して高水準の言語発達段階を要した.

4.メ夕表象能力の形成には, 平均聴力レベルのほ か, 言語発達年齢, 統語的に適切な構文産出が関与し ており, 補聴閾值や, MLUm 発達等の要因との関連 性は低かった。

本研究では, 主に, 中等度〜高度 (平均 $75.7 \mathrm{~dB}$, レンジ 46.2〜 $110 \mathrm{~dB}$ ）の聴障児を対象としており，全 例が聴覚音声コミュニケーションを用い, 言語発達遅 滞もおおむね 1 2 年の遅れの範囲にあった。聴覚障 害の重度例や手話等使用児については, 本結果の適用 は慎重でありたい。 また, Petersonは, 誤信念課題 通過には, 小児の言語的な相互交流経験の重要性を指 摘しており ${ }^{12)}$, 今後, 聴障児について聴児との遊び場 面での高次の表象的理解能力と会話成立との関連性に ついて解析を進めるとともに, 交流場面での他者の表 象的理解を促進する支援法の開発を進めることが要請 されている。

謝辞 本研究の実施にあたり，ご協力いただきました難聴児 施設の園児の皆さん, 本吉としえ先生, 豊田市こども発達セン ター長 高橋 修先生, 幼稚園の園児の皆さん, 先生方に心よ り打礼を申し上げます。

\section{文献}

1）子安増生 : 第 4 章「心の理論」研究の展開. 幼览期の他者 理解の発達, 京都大学学術出版会, 京都, 129-161頁, 1999.

2) Tager-Flusberg $\mathrm{H}$ and Sullivan $\mathrm{K}$ : A componential view of theory of mind: evidence from Williams syndrome. Cognition, 76: 59-89, 2000.

3) Perner J: Understanding Representational Mind, MIT Press, Cambridge, MA, 1991.

(小島康次, 佐藤 淳, 松田真幸訳 : 発達する〈心の理論〉, ブレーン出版, 東京, 96-140 頁, 2006.)

4) Tager-Flusberg $\mathrm{H}$ and Sullivan K: Predicting and explaining behavior: a comparison of autistic, mentally retarded and normal children. J Child Psychol Psychiatry, 35: 1059-1075, 1994.

5) Astington JW: The Child's Discovery of the Mind, Harvard University Press, Massachusetts, 1993.

（松村暢隆：子供はどのように心を発見するか, 新曜社, 東 京, 107-130 頁, 1995. )

6）志波泰子：幼児期の「心の理論」獲得におけるメ夕表象の 役割. 京都大学大学院教育学研究科紀要, 56:411-423, 2010.

7) Courtin C, Melot AM and Corroyer D: Achieving efficient learning: why understanding theory of mind is essential for deaf children and their teachers. Deaf Cognition: Foundations and Outcomes (edited by Marschark M and Hauser PC), Oxford University Press, New York, pp 102130, 2008.

8）山下裕司, 森田訓子, 氏田直子：難聴児の療育. Audiology Japan, 52(3) : 139-151, 2009.

9）廣田栄子：乳幼児難聴の聴覚医学的問題「早期診断と早期 療育に打ける問題点」. Audiology Japan, 56(3)：199211, 2013.

10) Geers AE: Spoken language in children with cochlear implants. Advances in the Spoken-Language Development of Deaf and Hard-of-Hearing Children (edited by Spencer $\mathrm{PE}$ and Marschark M), Oxford University Press, New York, pp 244-270, 2006.

11) Remmel $E$ and Peters K: Theory of mind and language in children with cochlear implants. J Deaf Stud Deaf Educ, 14(2): 218-236, 2009.

12) Peterson CC: Theory-of-mind development in oral deaf children with cochlear implants or conventional hearing aids. J Child Psychol Psychiatry, 45(6): 1096-1106, 2004.

13) Levrez C, Bourdin B, Le Driant B,et al: The impact of verbal capacity on theory of mind in deaf and hard of hearing children. Am Ann Deaf, 157(1): 66-77, 2012.

14) Ketelaar L, Rieffe C, Wiefferink $\mathrm{CH}$, et al: Does hearing lead to understanding? theory of mind in toddlers and preschoolers with cochlear implants. J Pediatr Psychol, 37(9): 1041-1050, 2012

15) Schick B, de Villiers $P$, de Villiers $J$, et al: Language and theory of mind: a study of deaf children. Child Dev, 78 : 376-396, 2007.

16）藤野 博, 福島邦博: 聴覚障害児における心の理論と言語 発達の関係。音声言語医学, $53: 69,2012$.

17）綿巻徹, 小椋たみ子：日本語マッカーサー乳幼児言語発 達質問紙「語と文法」手引, 京都国際社会福祉センター, 京都, 26-34 頁, 2004.

18) Bernstein DK and Tiegerman E: Language and communication disorders in children, Macmillan Publishing Company, 1993.

（池 弘子, 緒方明子, 山根律子：子どもの言語とコミュニ ケーション一発達と評価, 東信堂, 東京, 127-141 頁, 1994.)

19）宮田 Susanne, 大伴 潔, 西澤弘行： Exploring the developmental sentence score for Japanese (DSSJ): a 
comparison of DSSJ and MLU in spoken language samples from typically developing children and children with delayed development. コミュニケーション障害学, 24(2) : 88-100, 2007.

20) Figueras-Costa $B$ and Harris P: Theory of mind development in deaf children: a nonverbal test of falsebelief understanding. J Deaf Stud Deaf Educ, 6(2): 92-102, 2001.
21) Rieffe $C$ and Terwogt MM: Deaf children's understanding of emotions: desires take precedence. J Child Psychol Psychiatry, 41: 601-608, 2000.

別刷請求先：=471-0062 愛知県豊田市西山町 2-19

豊田市こども発達センター

難聴幼児通園施設なのはな

大原重洋 